\title{
ANALISIS REALISASI PENDAPATAN DAN BELANJA DINAS PENDIDIKAN INDRAMAYU BERBASIS WEB
}

\author{
Munengsih Sari Bunga'), Ahmad Lubis Ghozali ${ }^{2)}$ \\ ${ }^{12)}$ Program Studi Teknik Informatika \\ Politeknik Negeri Indramayu \\ Jl. Raya Lohbener Lama No. 8 Lohbener, Indramayu Jawa Barat Indonesia \\ nengslim85@ gmail.com ${ }^{1)}$, lubis@ polindra.ac.id)
}

\begin{abstract}
ABSTRAK
Pemasukan data-data transaksi keuangan yang berlangsung di Dinas Pendidikan Indramayu terkait laporan pendapatan dan belanja seperti penyaluran dana Bantuan Operasional Sekolah (BOS) dilakukan secara manual dan pengambilan data masih dilakukan secara langsung ke sekolah-sekolah. Transaksi keuangan hanya bisa dilakukan pada komputer lokal yang ada pada Dinas Pendidikan, sehingga bila staf keuangan atau orang yang bersangkutan sedang berada di luar maka tidak bisa melakukan transaksi. Sehingga perlu dibuat sebuah sistem informasi yang dapat membantu Dinas Pendidikan Indramayu dalam pengmabilan data laporan realisasi pendapatan dan belanja dari sekolah-sekolah mulai tingkat Sekolah Dasar sampai dengan Sekolah Menengah Pertama dari beberapa sekolah yang ada di Kabupaten Indramayu. Diharapkan dengan adanya sistem informasi yang berbasis web maka proses transaksi keuangan dalam hal laporan pendapatan dan belanja Dinas Pendidikan Indramayu dapat dilakukan dengan lebih mudah. Para staf keuangan dapat memproses transaksi keuangan secara cepat, Kepala Dinas dapat melihat keadaan keuangan dan realisasi penyaluran dana ke sekolah-sekolah meskipun tidak berada pada kantor dinas, dan pemeliharaan data dapat dilakukan dengan lebih mudah.
\end{abstract}

Kata Kunci: Dana Bantuan Operasional Sekolah, Laporan Realisasi Pendapatan dan Belanja, Web.

\begin{abstract}
The inclusion of data on financial transactions that took place in the Education Office of Indramayu related to income and expenditure reports such as School Operational Assistance (BOS) fund disbursement is done manually and data collection is still done directly to schools. Financial transactions can only be done on the local computer in the Education Office so that if the financial staff or the person is outside then cannot make a transaction. So it is necessary to create an information system that can help the Education Office Indramayu in getting data revenue and expenditure reports from schools ranging from elementary school to junior high school from some schools in Indramayu district. It is expected that with a web-based information system then the process of financial transactions in terms of income and expenditure reports Office of Education Indramayu can be done more easily. Financial staff can process financial transactions quickly, Head of Service can see the financial situation and the realization of the distribution of funds to schools even if not located in the office, and data maintenance can be done more easily.
\end{abstract}

Keywords: School Operational Assistance Fund, Revenue, and Expense Realization Report, Web. 


\section{PENDAHULUAN}

Dinas Pendidikan Indramayu mengemban tanggung jawab bagi tercapainya keberhasilan pembangunan bidang pendidikan sesuai dengan visi dan misi yang dicanangkan oleh Pemerintah Kabupaten Indramayu. Salah satu misi Dinas Pendidikan Indramayu adalah menyediakan layanan pendidikan yang merata dan terjangkau [1].

Program Bantuan Operasional Sekolah (BOS) oleh pemerintah ditunjukan untuk meningkatkan fasilitas pendidikan. BOS adalah program pemerintah untuk penyediaan pendanaan biaya non personalia bagi satuan pendidikan dasar dan menengah pertama sebagai wujud pelaksanaan program wajib belajar 9 tahun [2].

Dengan demikian, Dinas Pendidikan Indramayu yang menaungi bidang dinas pembinaan SD dan SMP mempunyai tanggung jawab untuk memonitoring dan mengevaluasi proses penyaluran bantuan dana BOS ke sekolah-sekolah. Namun proses transaksi keuangan dan realisasi penyaluran dana BOS ke sekolah-sekolah masih dilakukan secara manual dimana petugas Dinas Pendidikan Indramayu mengumpulkan secara langsung laporan realisasi pendapatan dan belanja terkait penggunaan dana BOS yang diterima dengan mendatangi sekolah-sekolah. Oleh karena itu, perlu dibuat sebuah aplikasi untuk menganalisis realisasi pendapatan dan belanja khususnya untuk penyaluran dana BOS. Maka perlu dirumuskan bagaimana membuat aplikasi berbasis web untuk menganalisis realisasi pendapatan dan belanja di Dinas Pendidikan Indramayu sehingga pelaporan dan pemeliharaan data dapat dilakukan secara teratur dan dapat membantu dalam mengumpulkan data bantuan dana untuk sekolah-sekolah di tingkat SD dan SMP.

Adapun tujuan penelitian yang ingin dicapai adalah sebagai berikut:

1. Mempermudah proses pengumpulan data laporan anggaran pendapatan dan belanja Dinas Pendidikan Indramayu.

2. Menganalisis data yang sudah tersimpan untuk kemudian dikelola dan ditampilkan dalam bentuk laporan realisasi anggaran dalam satu periode pelaporan.

3. Membantu pihak sekolah dalam melaporkan data laporan anggaran pendapatan dan belanja ke Dinas Pendidikan secara lebih cepat karena dilakukan secara online.

Manfaat yang diharapkan dapat diperoleh sebagai hasil dari penelitian ini adalah sebagai berikut:

1. Menghasilkan sebuah sistem informasi yang dapat digunakan dalam proses transaksi keuangan realisasi pendapatan dan belanja di Dinas Pendidikan Indramayu.

2. Menghasilkan sebuah sistem informasi yang dapat digunakan dalam melakukan pelaporan dan pemeliharaan data secara teratur.
3. Menghasilkan sebuah sistem informasi yang dapat digunakan dalam mengumpulkan data bantuan dana untuk sekolah-sekolah di tingkat SD dan SMP.

4. Hasil penelitian ini dapat dijadikan sebagai dukugan terhadap pemanfaatan teknlogi informasi oleh Lembaga Pemerintah maupun Swasta di Kabupaten Indramayu.

\section{TINJAUAN PUSTAKA}

Adapun kajian pustaka yang menjadi landasan dalam penelitian ini adalah sebagai berikut:

\section{Pengertian Sistem Informasi}

Sistem informasi adalah suatu sistem di dalam suatu organisasi yang mempertemukan kebutuhan pengolahan transaksi harian, membantu dan mendukung kegiatan operasi, bersifat manajerial dari suatu organisasi dan membantu mempermudah penyediaan laporan yang diperlukan [5].

Sistem informasi mencakup sejumlah komponen (manusia, komputer, teknologi informasi, dan prosedur kerja), ada sesuatu yang diproses (data menjadi informasi), dan dimaksudkan untuk mencapai suatu sasaran atau tujuan [10].

\begin{abstract}
Akuntansi
Menurut PP No.71 Tahun 2010 tentang Standar Akuntansi Pemerintahan basis akuntansi (pasal 1 ayat 8-9) terbagi atas : SAP yang mengakui pendapatan beban, asset, utang, dan ekuitas dalam pelaporan financial berbasis akrual, serta mengakui pendapatan, belanja, dan pembiayaan dalam pelaporan pelaksanaan anggaran berdasarkan basis yang ditetapkan dalam anggaran Pendapatan Belanja Negara/Anggaran Pendapatan Belanja Daerah APBN/APBD. SAP berbasis kas menuju akrual adalah SAP yang mengakui pendapatan, belanja, dan pembiayaan berbasis kas, serta mengakui asset, utang, dan ekuitas dana berbasis akrual. Dan basis akrual (accrual basis) sendiri adalah dasar akuntansi yang mengakui transaksi dan peristiwa lainnya pada saat transaksi dan peristiwa itu terjadi (dan bukan hanya pada saat kas atau setara kas diterima atau dibayar) [3].
\end{abstract}

\section{Konsep Belanja Pemerintah}

Standar Akuntansi Pemerintahan (SAP) menyatakan bahwa belanja diakui pada saat terjadinya pengeluaran dari Rekening Kas Umum Negara/ Daerah. Definisi lain berdasarkan Peraturan Menteri Dalam Negeri No.13 Tahun 2006 sebagaimana telah diubah dengan Permendagri no.59 Tahun 2007 dan adanya perubahan kedua 
dengan peraturan Menteri dalam Negeri N0.21 tahun 2011 tentang perubahan kedua, belanja dikelompokkan menjadi :

1. Belanja Langsung

Belanja langsung merupakan belanja yang dianggarkan terkait secara langsung dengan pelaksanaan program dan kegiatan. Belanja langsung adalah belanja yang terkait secara langsung dengan kegiatan (aktifitas) [6].

2. Belanja Tidak Langsung

Berdasarkan Peraturan Menteri Dalam negeri No.13 Tahun 2006 sebagaimana telah diubah dengan Tahun 2011 tentang perubahan kedua, belanja langsung dibagi menurut jenis belanja yang terdiri atas dari belanja pegawai yang dimaksudkan dengan pengeluaran honorarium / upah dalam melaksanakan program dan kegiatan pemerintah daerah seperti belanja pegawai, belanja modal, belanja barang dan jasa.

\section{Dinas Pendidikan Indramayu}

Secara umum Dinas Pendidikan Kabupaten Indramayu mengemban tanggung jawab bagi tercapainya keberhasilan pembangunan bidang pendidikan sesuai dengan visi dan misi yang dicanangkan oleh Pemerintah Kabupaten Indramayu. Mengacu pada Peraturan Daerah Kabupaten Indramayu Nomor 26 Tahun 2008 tentang Organisasi dan Tata Kerja Dinas Pendidikan Kabupaten Indramayu. Untuk melaksanakan tugas, pokok dan fungsinya, telah ditetapkan Organisasi Pemerintah Daerah (OPD) - Dinas Pendidikan yang merupakan salah satu unsur pelaksana di lingkungan Pemerintah Kabupaten Indramayu dibidang pendidikan. Unsur OPD-Dinas Pendidikan Kabupaten Indramayu dipimpin oleh seorang Kepala Dinas dan Sekretaris yang berada di bawahnya yang bertanggung jawab kepada Bupati Indramayu melalui Sekretaris Daerah, serta beberapa pelaksana yaitu Kepala Bidang, Seksi dan Subag, UPTD, dan kelompok jabatan fungsional (http://disdik.indramayukab.go.id/).

Dinas Pendidikan saat ini memiliki 31 UPTDPendidikan Kecamatan, dan UPTD-UPTD yang terdiri atas : 4 unit TK Negeri, 867 SD Negeri, 2 unit SDLB Negeri, 70 unit SMP Negeri, 20 unit SMPN Satu Atap dan 7 unit SMP Terbuka, 20 unit SMA Negeri, 19 unit SMK Negeri, dan 1 SKB, serta kelompok jabatan fungsional. Dalam melaksanakan tugas pokok dan fungsinya di bidang pendidikan, Dinas Pendidikan juga membina sekolah swasta yaitu 56 Kelompok Bermain, 397 SPS, 1 TPA, 362 TK, 3 SLB, 24 SD, 99 SMP, 31 SMA, dan 100 SMK. Di samping membina sekolah-sekolah yang berada di bawah naungan Departemen Pendidikan Nasional seperti tersebut di atas, Dinas Pendidikan juga membantu pembinaan penyelenggaraan sekolah yang berada di bawah naungan Departemen Agama yang meliputi : $101 \mathrm{RA}, 129 \mathrm{MI}, 78 \mathrm{MTs}, 31 \mathrm{MA}$ baik negeri maupun swasta yang berada di wilayah
Pemerintah Kabupaten Indramayu (http://disdik.indramayukab.go.id/).

Fungsi OPD-Dinas Pendidikan Kabupaten Indramayu merupakan unsur pelaksana Pemerintah

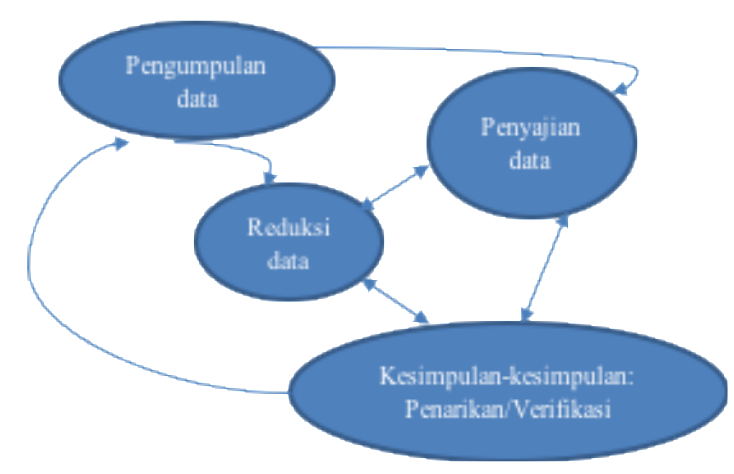

Gambar 1. Komponen Analisis Data dengan

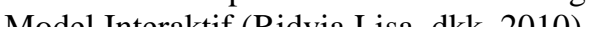

Daerah dibidang pendidikan, yang mempunyai tugas pokok melaksanakan wewenang Pemerintah Daerah dibidang Pendidikan. Untuk menyelenggarakan tugas pokok tersebut, Dinas Pendidikan mempunyai fungsi sebagai berikut (http://disdik.indramayukab.go.id/):

1. Perumusan kebijakan perencanaan teknis dan pelaksanaan koordinasi serta pengendalian dibidang Pendidikan.

2. Pelaksanaan teknis operasional dibidang pendidikan Pelaksanaan pelayanan teknis administrasi ketatausahaan.

3. Pelaksanaan pengelolaan UPTD-Pendidikan Kecamatan dan UPTD SKB.

4. Pelaksanaan kegiatan lain dibidang pendidikan sesuai dengan kebijakan Bupati.

Dalam penelitian ini mendefiniskan laporan realisasi anggaran pendapatan dan belanja Dinas Pendidikan Indramayu untuk memudahkan dalam pengelolaan data bagi pengguna akhir (end user) melalui sebuah aplikasi berbasis web. Laporan realisasi anggaran menurut PP No.71 tahun 2010 tentang Standar Akuntansi Pemerintahan, Laporan Realisasi Anggaran adalah menyajikan ikhtisar sumber alokasi dan pemakaian sumber daya keuangan yang dikelola oleh pemerintahan pusat/daerah, yang menggambarkan perbandingan antara anggaran dan realisasinya dalam satu periode pelaporan [11].

Peubah yang diamati/diukur dalam penelitian ini adalah melalui data pendapatan dan realisasi belanja Dana Bantuan Sekolah yang diterima dan digunakan secara langsung oleh Sekolah ditingkat SD sampai dengan SMP. Selain itu juga peubah yang diamati atau dikur adalah data pembelian barang/asset.

\section{METODE PENELITIAN}

\section{Teknik Pengumpulan Data}

Teknik pengumpulan data pada Penelitian ini dilakukan dengan menggunakan metode kualitatif. 
Teknik analisis data dilakukan dengan membandingkan antara nilai data realisasi dengan anggaran belanja dikalikan $100 \%$ untuk mendapatkan rasio anggaran belanja.

\section{Analisis Data}

Teknik yang digunakan dalam analisis data pada penelitian ini adalah secara deskriptif dan model yang digunakan adalah Model Analisis Interaktif Miles \& Huberman. Dengan menggunakan model tersebut maka analisis dilakukan dengan metode kualitatif yang pada dasarnya semua itu merupakan kegiatan penarikan sampel. Sampel diambil dari data-data sekolah-sekolah dari tingkat sekolah dasar sampai dengan sekolah menengah pertama. Berikut adalah model yang digunakan dalam penelitian dengan menggunakan komponen-komponen analisis interaktif Miles \& Huberman, seperti yang terlihat pada Gambar 1.

Dengan menggunakan model tersebut maka analisis dilakukan dengan metode kualitatif yang pada dasarnya semua itu merupakan kegiatan penarikan sampel. Sampel diambil dari data-data sekolah-sekolah dari tingkat sekolah dasar sampai dengan sekolah menengah pertama.

\section{Rancangan Penelitian}

Rancangan Penelitian dapat dilihat pada Gambar 2. Dimana tahapan yang dilakukan pada awal penelitian adalah perancangan yang dilanjutkan pada tahap berikutnya yaitu pembuatan aplikasi berbasis web dan setelah proses coding dilakukan maka aplikasi web yang dibangun siap digunakan.

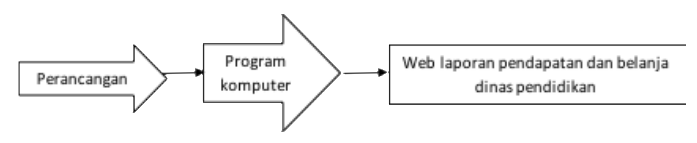

Gambar 2. Rancangan Penelitian

\section{Perancangan}

Pada tahapan perancangan ini yang dilakukan adalah membuat sebuah alur program dalam bentuk flowchart program yang menggambarkan alur dari aplikasi realisasi pendapatan dan belanja berbasis web di Dinas Kabupaten Indramayu seperti terlihat pada Gambar 3.

Terdapat 2 (dua) user yang dapat mengakses web laporan realisasi dan belanja Dinas Pendidikan Kabupaten Indramayu, yaitu Super Admin dan Admin Sekolah.

Super Admin merupakan Admin yang bertugas mengelola data di Dinas Pendidikan Kabupaten Indramayu yang mempunyai hak akses terhadap data sekolah tingkat SD dan SMP, laporan dari sekolah terhadap penggunaan anggaran dan pengumuman sebagai sarana informasi yang disampaikan ke sekolah-sekolah. Flowchart Super admin dapat dilihat pada Gambar 4.

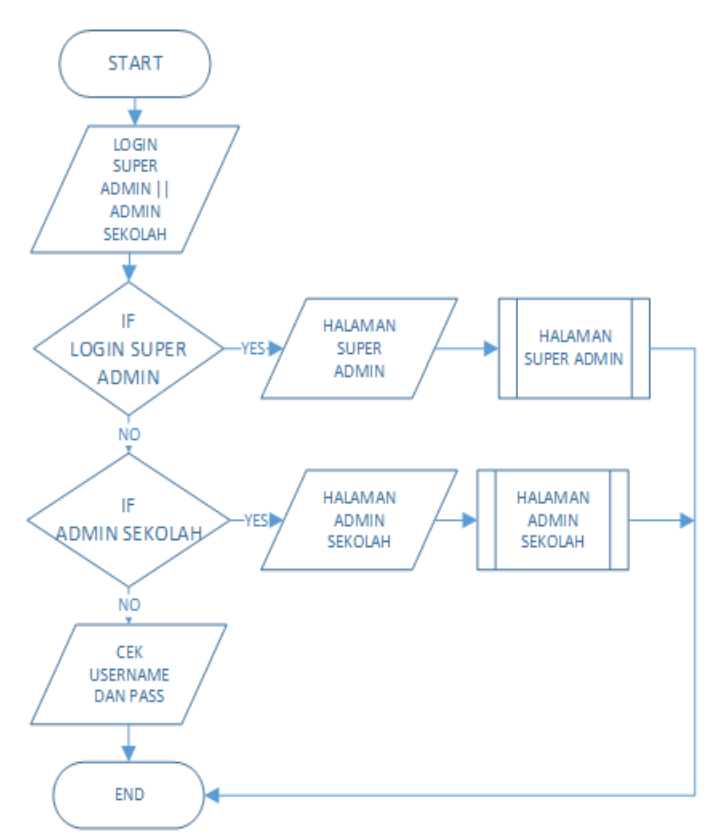

Gambar 3. Flowchart Program dari Web Realisasi Pendapatan dan Belanja

Sedangkan Admin Sekolah sebagai member atau anggota dari Web Realisasi Pendapatan dan Belanja Dinas Pendidikan mempunyai hak akses terhadap pengisian data profil sekolah, pengisian data laporan

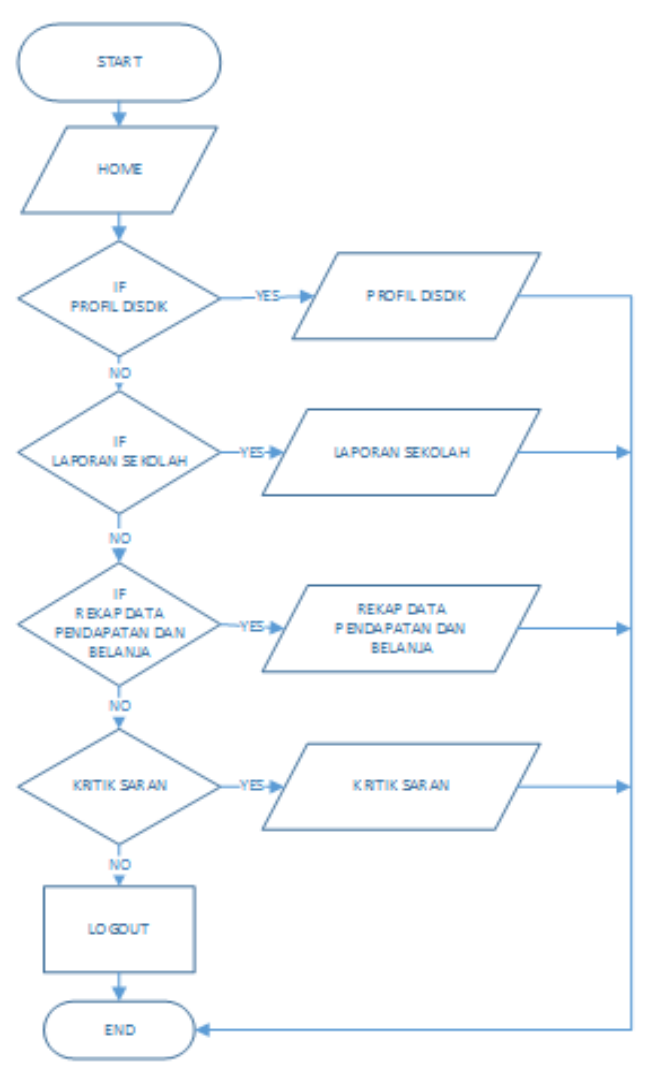

Gambar 4. Flowchart Program Super Admin 
pendapan dan belanja sekolah serta laporan. Flowchart admin sekolah dapat dilihat pada Gambar 5 .

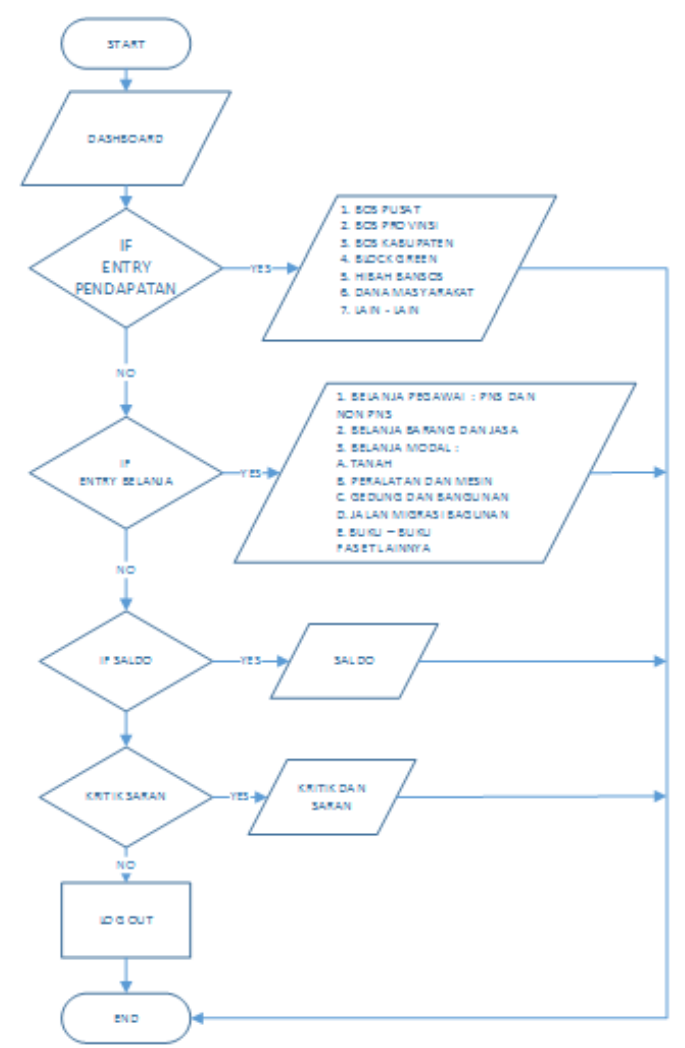

Gambar 5. Flowchart Program Admin Sekolah

\section{Program Komputer}

Pada tahapan ini merupakan tahap pembuatan software dengan melakukan Pengkodean Program (coding) sebagai proses utama dan sebagai langkah pembuatan software dimana proses sebelumnya yaitu perancangan sudah siap. Proses ini dilakukan untuk membuat tampilan software itu sendiri dan juga seperti apa program nantinya. Proses ini memakan waktu yang cukup lama dan membutuhkan tingkat ketelitian yang tinggi. Semakin tinggi ketelitian maka akan semain tinggi pula kualitas sebuah software.

\section{Aplikasi Web Realisasi Pendapatan dan Belanja Dinas Pendidikan Indramayu}

Setelah proses coding dilakukan maka sistem informasi yang dibangun siap digunakan. Sistem ini dibangun untuk membantu Dinas Pendidikan dalam melakukan rekap data pendapatan dan belanja serta penyebaran informasi ke seluruh Sekolah Dasar dan Sekolah Menengah Pertama di Indramayu.

\section{HASIL PENELITIAN \\ Hasil Penelitian}

Hasil dari penelitian ini adalah sebuah aplikasi yang dapat digunakan dalam proses transaksi keuangan realisasi pendapatan dan belanja berbasis web di Dinas Pendidikan Indramayu. Dengan aplikasi berbasis web maka pelaporan dan pemeliharaan data dapat dilakukan secara teratur. Dan aplikasi berbasis web ini juga dapat digunakan dalam mengumpulkan data bantuan dana untuk sekolah-sekolah di tingkat SD dan SMP.

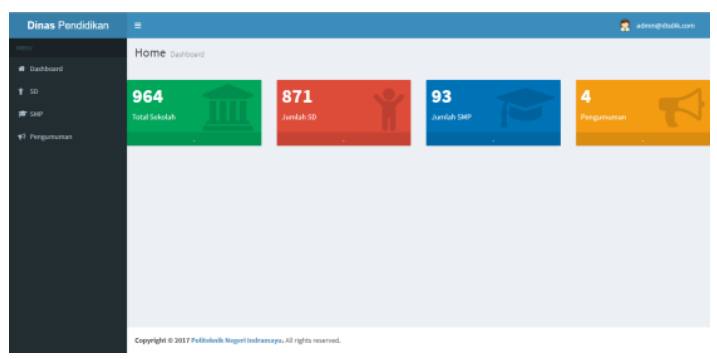

Gambar 6. Halaman Utama Super Admin

Aplikasi yang dibuat dapat digunakan oleh pihak Dinas Pendidikan Indramayu yang mempunyai hak akses terhadap laporan bantuan dana sekolahsekolah. Sedangkan pihak sekolah tingkat SD dan SMP sebagai user yang mempunyai hak akses dalam inputan data laporan realisasi pendapatan dan

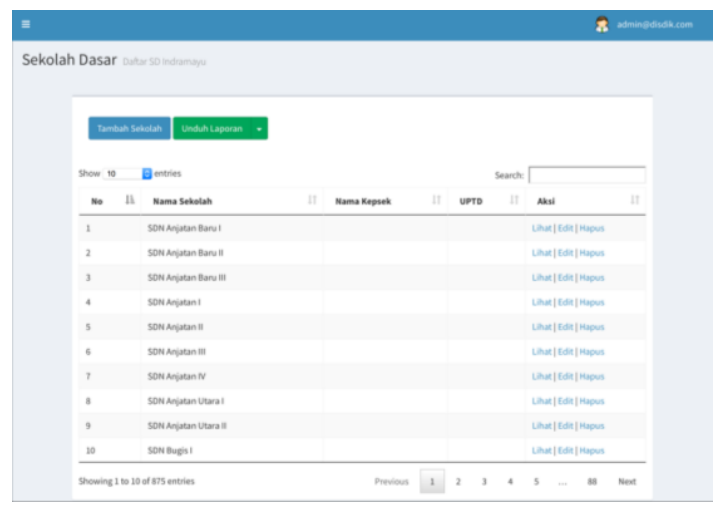

Gambar 7. Sistem CRUD Data Sekolah Dasar

belanja per tahun. Dengan adanya sistem informasi ini diharapkan dapat memudahkan petugas lapangan yang mengumpulkan data laporan di sekolah-

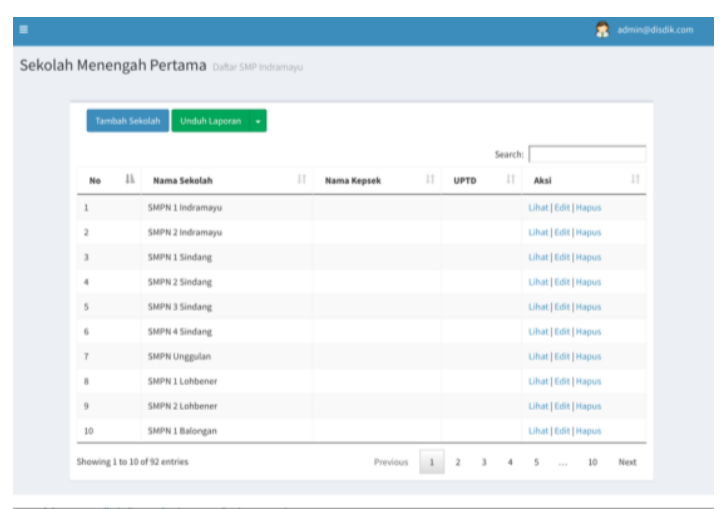

Gambar 8. Sistem CRUD Data Sekolah Menengah Pertama 
sekolah dengan lebih mudah dan lebih cepat karena dapat diakses melalui jaringan internet.

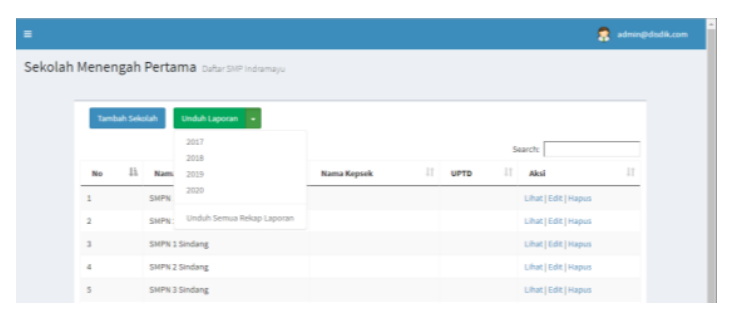

Gambar 9. Unduh Laporan Sekolah Pertahun

Tampilan dari aplikasi realisasi pendapatan dan belanja berbasis web di Dinas Pendidikan Indramayu dapat dilihat pada Gambar 6.

Pada halaman utama Admin terdiri dari menu SD dan SMP yang di dalamnya terdapat proses Create, Read, Update, dan Delete (CRUD) data sekolah seperti yang terlihat pada Gambar 7, Gambar 8.

Laporan data realisasi pendapatan dan belanja dapat dilihat pada menu Unduh Laporan yang ada

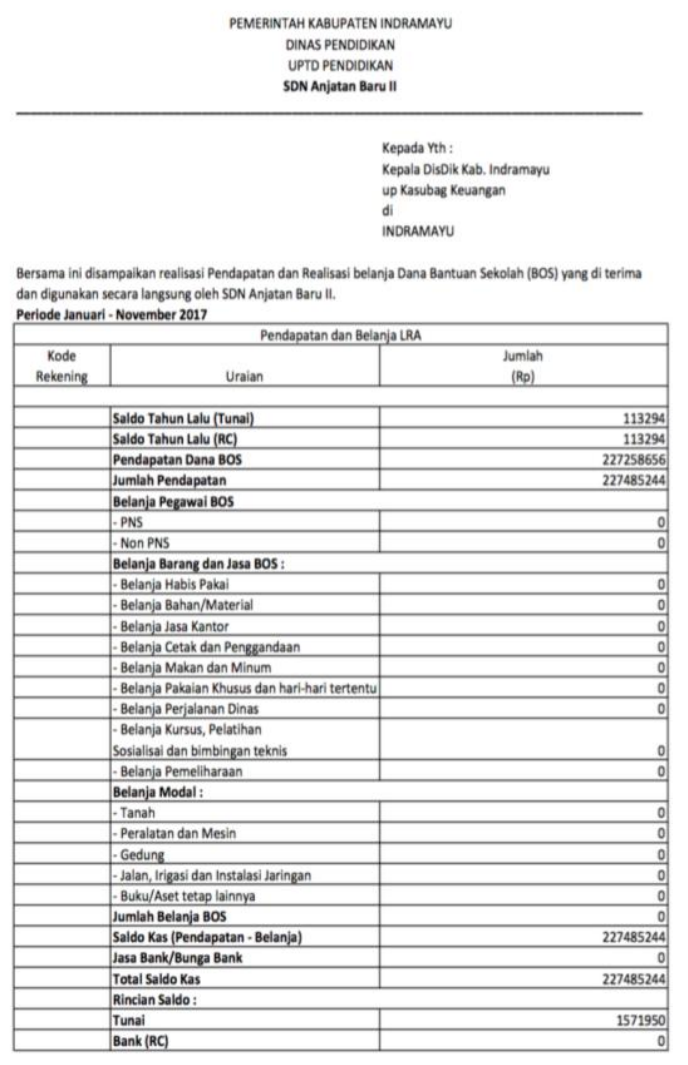

Demikian, Laporan Realisasi Pendapatan dan belanja yang kami sampaikan.

$$
\begin{aligned}
& \text { Indramaru, 10-11-2017 } \\
& \text { Kepala Sekolah, }
\end{aligned}
$$

pada menu SD dan menu SMP yang dapat dilihat pada Gambar 9, sehingga Dinas Pendidikan dapat dengan mudah melihat laporan dari sekolah tanpa datang secara langsung ke sekolah yang bersangkutan.

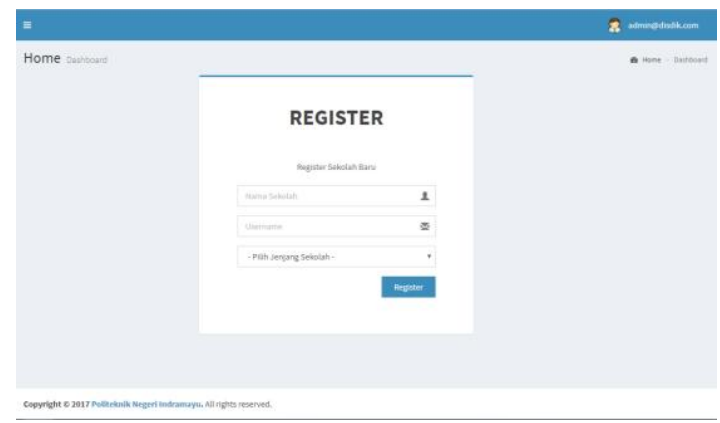

Gambar 11. Form Tambah Sekolah

Selain itu juga terdapat menu Pengumuman yang digunakan oleh Admin untuk menambah Pengumuman yang terlihat pada Gambar 12, dan berisi informasi yang dapat dilihat oleh sekolahsekolah ketika mengakses sistem informasi realisasi pendapatan dan belanja berbasis web.

Dinas Pendidikan Indramayu dapat langsung mengunduh laporan realiasasi pendapatan dan belanja dari sekolah-sekolah yang sudah memasukkan data laporan keuangan masing-masing sekolah. Form Laporan yang diunduh dapat dilihat pada Gambar 10.

Selain itu, Admin juga dapat menambah data sekolah dengan menekan tombol Tambah Sekolah maka akan muncul Form Tambah Sekolah seperti terlihat pada Gambar 11.

Admin dapat menambah pengumuman dengan menekan tombol Tambah Pengumuman sehingga akan muncul sebuah form yang harus diisi oleh Admin untuk memberikan informasi ke sekolahsekolah terkait laporan realisasi pendapatan dan belanja sekolah.

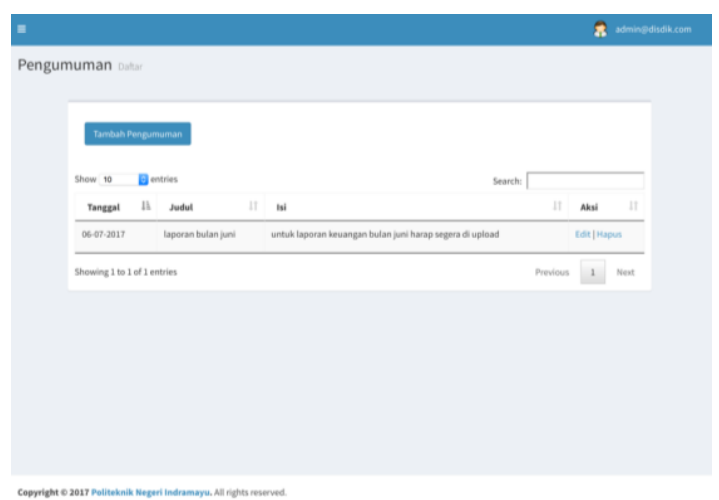

Gambar 12. Tambah Pengumuman

Gambar 10. Form Laporan yang diunduh 
Form tambah pengumuman dapat dilihat pada Gambar 13.

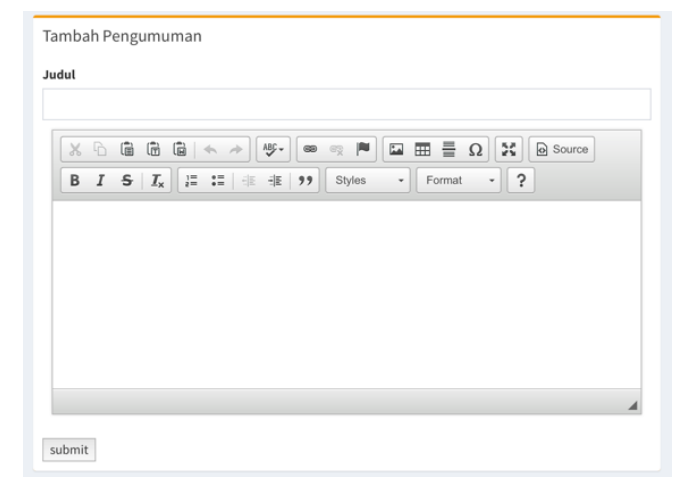

Gambar 13. Form Tambah Pengumuman

\section{KESIMPULAN}

Analisis realisasi pendapatan dan belanja di Dinas Pendidikan Indramayu dilakukan menggunakan sebuah aplikasi berbasis web yang dibangun untuk membantu Dinas Pendidikan Indramayu dalam melakukan rekap data pendapatan dan belanja sehingga diketahui perbandingan realisasi pendapatan dan belanja dari dana BOS tiap tahun serta penyebaran informasi terkait laporan pendapatan dan belanja seluruh Sekolah Dasar dan Sekolah Menengah Pertama di Indramayu.

\section{DAFTAR PUSTAKA}

[1] Admin. (2017). Visi Misi [online]. Available http://disdik.indramayukab.go.id/visi-misi/.

[2] Anonim. Program BOS [online]. Available http://www.tnp2k.go.id/.

[3] Halim, Abdul dan Kusufi, "Akuntansi Keuangan Daerah", Edisi 4, Jakarta: Salemba Empat, 2012.

[4] Hariyanto, Bambang, Sistem Manajemen Basis Data, Bandung: Informatika, 2004.

[5] Hartono, J., Analisa \& Desain Sistem Informasi : Pendekatan Terstruktur Teori dan Praktek Aplikasi Bisnis, Yogyakarta: Penerbit Andi, 2009.

[6] Mahmudi, Manajemen Kinerja Sektor Publik, Yogyakarta: YKPN, 2007.

[7] N Adrina. (2011). Chapter II - Pengertian Sistem Informasi [online]. Available http:// repository.usu.ac.id.

[8] Pressman, Roger, Software Engineering, A Practitioner's Approach, USA: McGraw-Hill, 2010.

[9] Ridvia Lisa, Maschandra dan Rusman Iskandar, Analisis Data Kualitatif Model Miles dan Huberman, Program Studi Magister Pendidikan Kejuruan Fakultas Teknik Universitas Negeri Padang, 2010.

[10] Sanny, Perancangan Aplikasi Keuangan Pada PT. Fresh On Time Seafood, Skripsi Program
Studi Sistem Informasi STMIK TIME MEDAN, 2015.

[11]U Rusita. (2015). Analisis efisiensi dan efektifitas pelaksanaan realisasi anggaran belanja langsung dinas pendidikan kota semarang [online]. Available http://eprints.dinus.ac.id/. 